\title{
Transformações no espaço doméstico - o fogão a gás e a cozinha paulistana, 1870-1930
}

\begin{abstract}
João Luiz Maximo da Silva ${ }^{1}$
RESUMO: Este artigo estuda algumas das transformações na cozinha paulistana, produzidas entre o último quartel do século XIX e as três primeiras décadas do século XX, pela introdução de novas premissas sanitárias, levadas a cabo por autoridades médicas e pela municipalidade. Além disso, procuramos discutir o papel das principais empresas de energia, como a The San Paulo Gas Company e, mais tarde, a The São Paulo Tramway Light and Power Company, na promoção da tecnologia do gás, e principalmente do fogão a gás - que elas oporão aos fogões a lenha e carvão. Estas empresas tiveram um importante papel na circulação de novas idéias de racionalização e higiene, contribuindo para a renovação do espaço doméstico que, pela tecnologia, passa a depender de um "sistema" de infra-estrutura destinado a articular, de uma forma inédita, o espaço privado ao espaço público.

PAlAVRAS-ChaVE: Cozinha. Publicidade. Fogão a gás. Trabalho doméstico. São Paulo.

ABSTRACT: This article examines some of the transformations in the kitchens of São Paulo brought about by the introduction of new sanitary concepts that were put into effect by medical and local government authorities in the last quarter of the $19^{\text {th }}$ century and in the first three decades of the $20^{\text {th }}$ century. In addition, we discuss the role played by the main energy companies, like The San Paulo Gas Company and, later, The São Paulo Tramway Light and Power Company in promoting the adoption of gas technologies, mainly the gas stove, as opposed to the use of firewood or charcoal for cooking. These companies played a key role in disseminating the new ideas about rationalization and hygiene, which contributed to change the household. Because of technology, the latter became dependent upon an infrastructure "system" that would articulate the private space with the public space in an unprecedented way.

KEYWORDS: Kitchen. Advertising. Gas Stove. Housework. São Paulo.
\end{abstract}

1. Doutorando no Programa de Pós-Graduação do departamento de História da Faculdade de Filosofia, Letras e Ciências Humanas da Universidade de São Paulo. E-mail: $<$ jlmaximo@hotmail.com>. 
2. Este artigo trata de alguns temas desenvolvidos na dissertação de mestrado de João Luiz Maximo da Silva (2002). Agradeço especialmente a colaboração do Professor Doutor Ulpiano T. Bezerra de Meneses, pela leitura crítica do texto e sugestões que enriqueceram a versão final

3. A empresa The San Paulo Gas Company foi constituída em Londres, em 1869, e iniciou seus trabalhos em 1872 , explorando a iluminação pública.Em 1900,passou a fornecer gás para fins domésticos e, em 1912, o grupo Light adquiriu o controle acionário da empresa. Cf. Comgás (1987).

4.A companhia de eletricidade teve como primeiro nome The São Paulo Railway Light and Power Company, mudando em seguida para The São PauloTramway Light and Power Company, para evitar confusão com a São Paulo Railway, que explorava as estradas de ferro. Iniciou seu funcionamento em São Paulo em 1900 e, no Rio de Janeiro, em 1905, já sob o nome de The Brazilian Traction Light and Power Company. Usaremos o nome pelo qual a empresa passou a ser chamada pela populacão,Light.A esse respeito,ver Edgar de Souza (1989).

5.A viabilização econômica da exploração de eletricidade exigia grandes investimentos e, em contrapartida, possibilitava grandes lucros. No final do século XIX e início do século XX, boa parte da expansão dos capitais estrangeiros investidos em serviços urbanos de utilidade pública ocorreu no ramo da energia elétrica, com empresas de grande porte controladas por grupos financeiros americanos e, principalmente, de capital britânico. A constituição geral do grupo Light no Brasil seguiu o processo característico deste tipo de empreendimento na época.A organização do gru-
Introdução

objetivo desse artigo² é discutir algumas das transformações da cozinha na casa paulistana entre 1870 e 1930. $\bigcirc$ ano de 1870 é considerado um marco fundamental para a história econômica e urbana de São Paulo por registrar um período de mudanças urbanas ligadas à expansão cafeeira, além do início de operações das empresas de energia que tratamos nesse artigo. $\bigcirc$ ano de 1930 foi escolhido como baliza final, pois, além de ser um marco político, representa também um momento de mudanças no relacionamento entre o governo e as empresas de energia. $\bigcirc$ modelo de concessão de exploração de energia para grupos estrangeiros, inaugurado com a The San Paulo Gas Company e consolidado com a Light, chegou ao fim junto com a República Velha.

Além do papel do poder público, procuramos avaliar a participação das empresas de energia (gás e eletricidade) no fomento de novos combustíveis e equipamentos domésticos, que tiveram um papel importante nessas transformações. Como desdobramento de suas atividades nos serviços urbanos, as empresas de energia procuraram desenvolver o consumo doméstico de gás e eletricidade e introduzir, sobretudo, o fogão a gás, procurando substituir seu principal concorrente, o fogão a lenha (e também a carvão). Nesse processo, foram importantes duas empresas de capital estrangeiro: a The San Paulo Gas Company ${ }^{3}$, constituída em Londres em 1869, e a The São Paulo Tramway Light and Power Company, constituída no Canadá em $1899^{4}$. Essas duas empresas, unidas mais tarde no grupo Light, foram as grandes responsáveis pela introdução do gás e da eletricidade em grande escala na cidade de São Paulo a partir do final do século XIX

Uma das questões que devemos considerar é o resultado do impacto provocado pelas novas empresas e seu papel em um processo mais amplo, que envolvia aspectos da urbanização levada a cabo pelo poder público. Esse período trouxe uma ruptura com o passado, e a casa paulistana foi fortemente modificada nesse processo de atualização, entrando em choque com antigas práticas. No espaço dessas novas residências, os equipamentos domésticos a gás tiveram um papel central, pois propiciaram uma nova configuração espacial; e novas relações de trabalho e convivência doméstica. Empresas como a Light representavam um ideal de progresso endossado por nossas elites. Além disso, foram o ponto de ligação da casa com o espaço urbano, por via das redes de distribuição de energia e da prestação de serviços técnicos, um fenômeno novo na cidade de São Paulo. Esse processo revelou um forte descompasso entre a realidade social brasileira e sua representação pelos grupos estrangeiros que procuravam explorar o grande crescimento urbano de cidades como a capital paulista. Nesse contexto, o papel das empresas e da publicidade foi decisivo para vencer resistências e escamotear dificuldades e ônus. 
po foi precedida por um corpo jurídico, destinado a resolver problemas legais referentes à obtenção e à ampliação de concessões.Além disso, era necessário contato com o poder e as elites do local da implantação dos serviços, visando a obtenção e ampliação das concessões, monopolização gradual dos serviços urbanos, para a maximização dos lucros. O poder público municipal, sem capacidade de investimento, oferecia concessões para exploração deste tipo de atividade.A esse respeito ver Tamás Szmrecsányi \& Flávio A M. Saes (1992,p. 14-15); e Renato Feliciano Dias (1988, p. 34-43). presença de empregados nos lares (GIEDION, 1948, p. 23). Antes mesmo da mecanização dos fogões e outros equipamentos, que determinaram mudanças na cozinha, um componente importante foi a crescente preocupação com a organização do espaço da casa e suas atividades. Segundo Giedion (1948, p. 51 8-5191, o marco inicial desse movimento foi a publicação, em 1841, do manual Treatise on domestic economy, de Catherine Esther Beecher. $\bigcirc$ objetivo da autora era o ensino de economia doméstica para donas de casa e a organização das tarefas na cozinha. Sua preocupação era com a racionalização das tarefas domésticas a cargo da mulher, lançando as bases para a organização do processo de trabalho doméstico, à semelhança do que acontecia com o trabalho nas fábricas.

Prosseguindo em seus estudos, Beecher lançou em 1869 a obra The American woman's home, em que analisava a importância do planejamento da cozinha e do estabelecimento de superfícies de trabalho, que facilitariam o movimento da dona de casa na execução das tarefas. Se nos primeiros modelos de cozinha o fogão era colocado separado do restante do espaço, com o desenvolvimento do fogão compacto de ferro, aconteceu o ajuste perfeito do novo equipamento à superfície contínua de trabalho, já preconizado pela educação doméstica.

Os fabricantes americanos de aparelhos domésticos se interessaram pelas pesquisas de organização da cozinha. A partir de 1912, Christine Frederick empreendeu estudos de gestão científica da rotina diária da casa e movimentos da dona de casa na execução das tarefas. Esse processo era defendido por grupos femininos, como as chamadas material feminists, que pregavam a total coletivização dos trabalhos domésticos. Elas propunham remuneração para o trabalho da dona de casa, transformação espacial e material das casas, e criação de cozinhas coletivas. A infra-estrutura propiciada pelas empresas de serviço (gás e eletricidade) e o surgimento de equipamentos domésticos atendiam às demandas desses grupos (HAYDEN, 1981, p. 6). Nesse processo, os engenheiros tiveram um papel importante, no desenvolvimento de novas formas de organização espacial e no estudo dos movimentos necessários para a 
6. Cf. Paulo Bruna (1998) e Margareth Rago (1987).

7. Maria Cecília Naclério Homem (1996) analisa o desenvolvimento da privacidade $\mathrm{e}$ da higiene nas moradias isoladas européias dos séculos $\mathrm{XVI}$ ao XVIII, que teriam influenciados os palacetes paulistanos nas últimas décadas do século XIX execução das tarefas domésticas. A mecanização das tarefas domésticas e o fornecimento de gás e eletricidade nas casas reforçaram esse processo.

Se nos Estados Unidos os engenheiros tiveram um papel primordial na reorganização do trabalho doméstico, na Europa foram os arquitetos que tomaram a frente nas pesquisas, sem o componente social representado pela Guerra da Secessão do caso americano. Arquitetos europeus desenvolveram projetos como a "cozinha de Frankfurt", um espaço altamente especializado e de tamanho reduzido. Esta cozinha se destacava pela padronização dos componentes e disposição dos equipamentos (fogão, pia e armários) em superfície contínua de trabalho. O ponto de partida destas pesquisas foi o livro Household engineering: scientific management in the home, de Christine Frederick, publicado em 1915 pela American School of Home Economics (BRUNA, 1998, p. 18).

A organização da cozinha visava a atingir uma simplificação das tarefas, com a economia de movimentos, e o barateamento dos equipamentos, a partir da produção em grande escala. A idéia deste tipo de cozinha era liberar a mulher para o mercado de trabalho, diminuindo e simplificando ao máximo o trabalho doméstico. A padronização e racionalização da habitação e seus componentes visava a uma radical transformação da casa, em especial da cozinha, e apoiava-se tanto no desenvolvimento de novos equipamentos, quanto nos estudos de racionalização do trabalho doméstico. A principal preocupação era o desenvolvimento de um novo tipo de habitação, que deveria induzir um novo comportamento social. Os novos equipamentos domésticos e a racionalização do trabalho estariam a serviço de uma nova forma de morar em casas concebidas como "máquinas de morar" (BRUNA, 1998, p. 27-44).

Esse movimento arquitetônico e social é que teria influenciado as discussões sobre habitação social no Brasil a partir da década de 1930. Em maio de 1931, sob o patrocínio da Prefeitura e do Instituto de Engenharia de São Paulo, realizou-se em São Paulo o I Congresso de Habitação. O parâmetro para esse congresso era justamente o debate da arquitetura européia acerca da intervenção na vida das classes trabalhadoras por intermédio da construção de moradias 6 . A partir da década de 1930, começam a ser discutidos no Brasil os princípios de racionalização do trabalho. Segundo Maria Cecília N. Homem (2003, p. 125-126) o Idort (Instituto de Organização Racional do Trabalho) começou a publicar em sua revista uma série de artigos, inspirados em princípios da engenharia norte-americana, sobre a aplicação de princípios de racionalidade na cozinha.

Mas, antes disso, as preocupações com a cozinha e o trabalho doméstico foram introduzidas com a medicina sanitária e a oferta de gás e eletricidade para uso doméstico no início do século XX. E as residências das elites urbanas por sua vez, foram influenciadas pelo surgimento de moradias isoladas na Europa do século XVIII, que estavam associadas a noções de conforto e intimidade?. A diversificação das moradias na cidade de São Paulo trouxe as primeiras preocupações com novas formas de morar e organizar as atividades domésticas. Em nosso caso a dimensão política e social também estaria ausente, como veremos a seguir. 
grande crescimento da cidade de São Paulo a partir das últimas décadas do século XIX gerou um aumento e diversificação dos padrões de moradia na cidade. A abertura de novas áreas estava diretamente ligada ao estabelecimento de um mercado imobiliário cada vez mais atuante. $O$ crescimento demográfico e o desenvolvimento econômico provocavam uma grande demanda por habitações para várias camadas da população. Além dos loteamentos para classes mais abastadas, havia também o crescimento de cortiços na área central, a construção de moradias para aluguel e casas para operários, evidenciando uma grande segmentação. Se, até 1870, do ponto de vista da renda, a propriedade da terra era pouco relevante, com o desenvolvimento econômico, o mercado imobiliário tornou-se extremamente lucrativo, atraindo capital antes imobilizado na posse de escravos (ROLNIK, 1997, p. 102). O centro (área conhecida como Triângulo ${ }^{8}$ ) sofreu grandes transformações, com a regularização de suas ruas e expulsão das camadas mais pobres para transformar em espaço de comércio elegante. Houve uma especialização funcional da região e, em conseqüência, sua remodelação, com a construção de bulevares, derrubada de quarteirões e proibição de cortiços no perímetro comercial lque coincidia com o referido Triângulo), estabelecida pelo Código de Posturas de 1875 (revisto e ampliado em 1886) 9 .

Foi nesse universo de novos tipos de ocupações residenciais em São Paulo que se definiu o espaço da cozinha, distanciando-se da imagem característica da área de serviço da antiga casa paulistana. A imagem que chegou até nós da cozinha da casa de padrão bandeirista ${ }^{10}$ sugeria trabalho pesado e sujo, desenvolvido longe das áreas de estar. Todo o serviço era concentrado nesse local. A descrição de John Mawe, que visitou São Paulo em 1807, é bem representativa da imagem dessa cozinha:

Para dar uma idéia da cozinha, que deve ser a parte mais limpa e asseada da habitação, - leitor pode imaginar um compartimento imundo com chão lamacento, desnivelado, cheio de poças d'água, onde em lugares diversos armam fogões armados por três pedras redondas, onde pousam as panelas de barro, em que cozinham a carne; como a madeira verde é o principal combustível, o lugar fica cheio de fumaça, que, por falta de chaminé, atravessa as portas e se espalha pelos outros compartimentos, deixando tudo enegrecido pela fuligem. Lamento ter que afirmar que as cozinhas das pessoas abastadas em nada diferem destas (MAWE, 1944, p. 84).

Não é apenas nas descrições de viajantes que temos esta imagem de cozinha. $\bigcirc$ poeta Guilherme de Almeida, em uma conferência sobre habitações, evoca as recordações sobre a casa de sua infância no final do século XIX: "Vem agora a cozinha, enorme e preta de fuligem, onde a negrada acocorada contava histórias tenebrosas, sob a telha-vã povoada de gambás e morcegos, e com um chão de alçapões que desciam para infernos ignorados" (ALMEIDA, 1942, p. 178-179).
8.A região era conhecida como Triângulo porque abrangia o perímetro das ruas $\mathrm{Di}$ reita, São Bento e XV de Novembro, que formavam um "triângulo", constituindo o núcleo central da cidade.

9. O Código de 1886 seria uma recodificação, sem necessidade de solicitação de aprovação provisória à presidência da província. Foi aceito pela Câmara em 6 de outubro de 1886 e entrou em vigor imediatamente, incorporando posturas aprovadas após 1875 . Consultamos a versão, ampliada e revista em 1886, do Código de Posturas de 1875 , na edição de 1940, do Departamento de Cultura. A esse respeito, ver Eudes Campos Júnior (1997, p. 605).

10. Cf. Carlos Lemos (1978). 
A dispersão da cozinha no quintal da casa também atendia às necessidades do trabalho doméstico. Devido à sujeira e à escala do preparo das refeições (que envolvia atividades pesadas e demoradas), o trabalho era feito fora do corpo principal da casa. Podemos dizer que, como espaço circunscrito e especializado de preparo dos alimentos, a cozinha não existia. $\bigcirc$ que aparece nas plantas e descrições deste espaço nos primeiros séculos é uma grande área destinada aos serviços, que incluíam preparo, estocagem e beneficiamento de alimentos, além da criação de pequenos animais. Segundo Carlos Lemos (1978, p. 65), a cozinha formava "um complexo que envolvia fogão, tanque, bica, cisterna, paiol, despensa, curral e pomar, situação que permaneceu até o século XIX".

O espaço da cozinha era importante na definição dos novos padrões de moradia do final do século XIX em São Paulo. Prova disso era a preocupação das autoridades públicas e a tentativa de padronização através dos códigos de posturas e sanitário. O grande alvo das autoridades foi a péssima condição das cidades. Epidemias, como a de febre amarela em 1893, levaram o poder público a medicalizar sua atuação. A necessidade de melhor circulação das mercadorias - e a de uma crescente elite - tornou a salubridade a principal meta na melhoria das cidades. A medicina aliou-se ao novo sistema - contra a antiga ordem colonial - e, por intermédio da higiene, incorporou a cidade e a população ao campo do saber médico (COSTA, 1999, p. 79).

A higiene (física e social) teve um papel decisivo nas transformações da cozinha nos centros urbanos brasileiros. Ao contrário dos Estados Unidos, onde os engenheiros estavam no primeiro plano, e da Europa, onde a arquitetura centralizava as discussões, no nosso caso, as autoridades médicas tiveram um papel de destaque, apoiadas pelas autoridades públicas. Num contexto de epidemias e necessidade de limpeza e organização da cidade, as antigas moradias - e o espaço da cozinha em particular - despertaram a atenção das autoridades.

Tão importante quanto no espaço urbano, era a intervenção na família e na casa, visando a incorporá-la não apenas a uma nova realidade citadina, mas à lógica imposta pela salubridade. A modificação do perfil arquitetônico serviria para aumentar o intercâmbio entre o ambiente doméstico e o meio social (COSTA, 1999, p. 79). Apesar da importância da medicina sanitarista nesse processo, ele também envolveu engenheiros, autoridades públicas e, ainda, serviu aos interesses dos fornecedores de serviços urbanos e de objetos para consumo (como veremos adiante), sobretudo domésticos: "Indústria e comércio internacionais precisavam modernizar a rede de serviços urbanos a fim de escoarem seus produtos. A modificação do comportamento da família era um dado importante nessa estratégia" (COSTA, 1999, p. 153).

Na questão da salubridade, o ponto extremo era a situação dos cortiços. $\bigcirc$ Código de 1875 (e principalmente a versão revista e ampliada de 1886) tratava das normas referentes à construção de cortiços, estabelecendo metragens mínimas e a existência de pelo menos três cômodos, incluindo a cozinha. Na verdade, o grande crescimento da cidade e a ocorrência de 
epidemias levaram o governo a abordar o assunto e, posteriormente, a intervir no espaço das casas. As primeiras legislações apenas davam orientações gerais, sem jamais cogitar de intervenção no planejamento interno das residências. $\bigcirc$ crescimento das cidades e o conseqüente aumento dos problemas fizeram os especialistas repensarem tal questão. A modificação material estava intimamente associada à moralidade, principalmente nas camadas mais pobres, vistas como potencialmente perigosas.

Higiene e arranjo material

Neste ponto, o principal alvo das autoridades eram os cortiços, que proliferavam em cidades como São Paulo. Em 1885, o Dr. Eulálio da Costa Carvalho, médico da Câmara paulistana, e o engenheiro Luís César do Amaral Gama fizeram relatórios a respeito da relação entre as péssimas condições de higiene dos cortiços e as epidemias que assolavam a cidade (LEMOS, 1999, p. 18$)^{11}$.

Em 1893, com a epidemia de febre amarela, o Dr. Cesário da Motta Junior, secretário dos Negócios do Interior do Estado de São Paulo, constituiu uma comissão para fazer um relatório das condições dos cortiços na região de Santa Efigênia. O relatório trouxe uma ampla descrição das condições de higiene nesse tipo de habitação e, com ele, podemos perceber a importância da cozinha na definição de um espaço doméstico organizado e limpo. A situação dos cortiços era o contra-exemplo do ideal de habitação, na medida em que a cozinha não estava definida, e suas atividades eram feitas de forma precária, sem higiene, dividindo o espaço com o quarto de dormir. Descrevendo um cortiço localizado no meio de um quarteirão, o relatório apontava as condições da cozinha:

São estas casinhas em geral assoalhadas, forradas nos cômodos de dormir, e na sala de frente, sem outro sistema de ventilação que o natural por intermédio das janelas e portas. No cômodo do fundo onde não há soalho nem forro, nem mesmo ladrilhos, assenta um fogão ordinário e rudimentar com chaminé que pouco funciona em vista de sua má construção ou do pouco cuidado que se lhe tem. Daí vem que o interior dessas pequenas casas tem as paredes enegrecidas e pouco asseadas, do teto já se não lhes conhece a pintura sob a camada de sujeiras das moscas. As paredes com quadros de mau gosto tem o reboco referido por uma infinidade de pregos e trincas que pendem vários objetos de uso doméstico e a roupa de serviço. Os móveis desagradavelmente dispostos tem sobre si empilhadas peças de roupas para lavar ${ }^{12}$.

A posição da cozinha é característica da maioria das casas do período, localizada nos fundos, mas sem nenhum tipo de organização e com domínio da sujeira. Na verdade, não parecia haver uma cozinha propriamente dita, mas um espaço que seria improvisado para esse fim. $\bigcirc$ fogão (provavelmente um a lenha) parecia ter um papel de destaque na definição do espaço, causando
11. Existe uma gama de documentações envolvendo os diversos atores sociais implicados na questão do processo de higiene e sanitarização da cidade de São Paulo no período. Documentos - como os relatórios do poder público sobre moradias, além do debate em revistas médicas e o próprio Código Sanitário - foram muito utilizados por vários pesquisadores na análise das transformações urbanas e sociais da cidade de São Paulo.A esse respeito,ver Maria C. N. Homem (1993); Raquel Rolnik (1997); e Maria Ruth Sampaio (1998).

12. SÃO PAULO (Prefeitura), 1893, [n.p.]. 
a sujeira, pela fumaça que enegrecia as paredes. Além de descrever a sujeira e desorganização da cozinha - que dividia espaço com outras funções, o que era combatido pelas autoridades -, o autor do relatório também aponta o "mau gosto" na organização do espaço, seja devido aos quadros, seja devido à disposição do mobiliário.

Devemos lembrar que, nesse momento, as noções de organização e limpeza do espaço doméstico incluíam também o arranjo do mobiliário doméstico, visando a uma melhor eficiência do trabalho. É claro que as condições de um cortiço estavam muito distantes deste ideal, mas a descrição do relatório parece bastante sugestiva na definição da importância de características materiais da casa e de sua organização. A localização da cozinha também era alvo de críticas das autoridades: "A cozinha, quando não é ao lado da latrina, está assentada junto do aposento de dormir e, então, as condições de asseio são as mais precárias possíveis"13.

Situação mais preocupante ainda era o caso dos sobrados convertidos em cortiço, onde a cozinha era coletiva: "uma sala com vários fogões improvisados, para gozo de todos, umas latrinas pessimamente instaladas e compridos corredores com iluminação insuficiente"114.

Nos relatórios também fica visível uma grande preocupação com dados da vida material e dos hábitos cotidianos nos cortiços. O fogão e demais mobiliários da cozinha teriam um papel importante nas novas práticas preconizadas pelas autoridades. A conclusão da comissão de técnicos é de que a área devia ser desapropriada e os cortiços demolidos, deslocando a população para "vilas operárias" a serem construídas. Este relatório teria influenciado o Código Sanitário promulgado em 1894. Devemos lembrar que, apesar de não serem os cortiços o alvo dos novos equipamentos domésticos, colocados à disposição dos consumidores mais abastados, a improvisação (ou ausência) da cozinha era o símbolo do que deveria ser evitado pelas autoridades públicas e médicas, sendo esse tipo de moradia uma referência apropriada para as autoridades no tocante ao sanitarismo.

O Código Sanitário de 1894 ainda era essencialmente indicativo e deixou várias questões sem regulamentação. Em relação às cozinhas, exigia uma barra de impermeabilização de 1,50 m de altura a partir do piso e proibia a comunicação direta com os quartos. A cozinha, muitas vezes considerada como o "laboratório" da casa (segundo a visão das propagandas de fogão a gás), era vista pelas autoridades como um espaço primordial na organização e limpeza da casa. Outro dado que chama a atenção é o tamanho exíguo, muitas vezes com cerca de $4 \mathrm{~m}^{2}$ (LEMOS, 1999, p. 37). Para as elites e autoridades, a importância de um espaço adequado era tão grande, que os primeiros hotéis da cidade planejavam oferecer serviços que não estavam disponíveis nas casas paulistanas. Em relatório aos acionistas, publicado no Diário Oficial do Estado de São Paulo, de 5 de setembro de 1893, o diretor da Companhia São Paulo Hotel assim se refere a esta questão: 
Parece-me mais acertado e prudente que a companhia, tendo por fim explorar a indústria de hotéis, longe de vender precipitadamente os terrenos da chácara, montasse ali um hotel modelo, com todas as comodidades e dependências que a civilização moderna aconselha e exige nos estabelecimentos de primeira ordem, aproveitando-se a excelente e vasta área da chácara para fundar uma vila, edificando-se prédios pequenos, elegantes, baratos, decentes e confortáveis, para famílias as quais dependentes do Grande Hotel, seriam uma excelente fonte de renda e viriam resolver o grande problema da falta de casas para vivenda regular, com criados e cozinhas, o grande pesadelo de família nesta rica e florescente cidade (BRITO, 2000, p. 48).

A proposta do diretor da Companhia Grande Hotel parece uma solução original, com o hotel servindo como cozinha para grupos de famílias, constituindo-se em uma vila para famílias abastadas. Devemos ressaltar que, em outros países, os primeiros fogões a gás foram instalados em hotéis e restaurantes. Um dos primeiros fogões a gás foi construído pelo um proprietário de um restaurante de Glasgow e apresentado na Grande Exposição de 1851 (GIEDION, 1948, p. 541).

Enquanto os novos aparelhos eram testados nos hotéis e restaurantes da Europa, no Brasil o governo tentava intervir no espaço doméstico por meio de leis visando à higienização. A Lei municipal n. 375, de 1898, em seu artigo 28, definia as habitações operárias "com mais de um repartimento, cozinha, esgoto, observando as prescrições de higiene e asseio, dos regulamentos sanitários". A Lei municipal n. 498, de 14 de dezembro de 1900, estabeleceu prescrições para construção de casas de habitação operária, que deveriam ser localizadas fora do perímetro urbano, entre outras, estabelecendo o mínimo de três cômodos, incluindo a cozinha.

A construção de vilas operárias parecia ser a solução para o problema representado pelos cortiços. Elas seriam o contraponto das habitações precárias, na medida em que haveria uma divisão clara dos cômodos da casa, em especial da cozinha, ficando ela livre da superposição de funções que ocorria no cortiço. As vilas operárias eram consideradas soluções saudáveis, com casas higiênicas, modernas e baratas. Apesar disso, eram poucos os exemplos de vilas operárias, a maioria localizada junto às fábricas. Vários construtores tinham interesse nesse tipo de moradia, mas pediam, no entanto, a concessão de terrenos ao governo do estado de São Paulo, para construção de três tipos de casas, como vemos, em 1914, nessa notícia no Boletim do Departamento Estadual do Trabalho:

Para pequena família, compostas de sala, um quarto, cozinha e tanque para lavagem de roupa, latrina e banho de chuva no quintal; para família maior, compostas de uma sala, dois quartos, cozinha e tanque para lavagem de roupa, latrina e banho de chuva no quintal; casas apropriadas para armazéns, açougues, padaria, etc. ${ }^{15}$

A individualização das casas para diferentes tipos de família e a presença de cozinha em seu interior era a imagem ideal da casa destinada às populações mais pobres. Esse padrão aproximava-se da casa das classes mais abastadas, ao menos no que diz respeito à exigência de higiene e áreas
15. SÃO PAULO (Estado) 1911-1927, n. 8 e 9. 
16. Cf. Francisco Figueira de Mello (1926, p. 295).

17. Idem, p. 291-294.

18. A esse respeito ver o trabalho de Maria Auxiliadora Guzzo Decca. No interior da morada operária... (1984, p. 97-109).

19. Cf. Victor Silva Freire 1918 , p. 240 separadas para cada atividade, notadamente a cozinha. A Lei municipal $\mathrm{n}$. 493, de 1901, isentava de impostos municipais as vilas operárias e não permitia as habitações coletivas em forma de cortiço. A despeito disso, os cortiços aumentavam, e a situação da cozinha permanecia a mesma, à revelia das autoridades. A existência de cortiços e cozinhas insalubres continuava a ser denunciada pelas autoridades médicas.

\section{Código sanitário e Padrão Municipal}

Os problemas e as preocupações dos médicos com os cortiços continuaram durante as primeiras décadas do século XX, como podemos perceber em revistas médicas do período:

Nesses cortiços não moram, amontoam-se os pobres seres, e, telheiros de zinco, em porões, nos quais seres irracionais não ficariam! [...] Pois, encontramos em um cortiço, num só cômodo, reunidos a cozinha e a privada! E note-se que visitamos um bairro relativamente central, em que as condições de vida não são de todo más ${ }^{16}$.

Na visão dos médicos, a questão das habitações populares era de interesse médico-social. Ainda na década de 1920, o Dr. Francisco Figueira de Mello chamava a atenção para a necessidade de resolução do problema, que teria repercussões morais. Analisando dados sobre 116 cortiços na região do bairro de Santa Efigênia, o médico constata, estarrecido, a ausência de cozinhas em $95,32 \%$ das unidades dos cortiços ${ }^{17}$.

E as descrições de cozinhas (ou da ausência delas) nos cortiços continuaram a ser publicadas nas décadas de 1920 e 1930'18, apesar de continuar a ser modificada a legislação sobre o assunto, sempre tendo em vista os conselhos de médicos e engenheiros. Os trabalhos de infra-estrutura urbana também influenciaram essa transformação, e mesmo as casas mais pobres sofreram influências.

O Código Sanitário de 1918, no artigo 389, que discutia os cortiços, estabelecia o papel da cozinha na casa e, mais ainda, de seus principais equipamentos, como o fogão: "É terminantemente proibido cozinhar, a não ser nas cozinhas, que deverão ser instaladas, munidas de fogão e pias para a lavagem de louça" ${ }^{\prime 1}$. A legislação procurava ser precisa, definindo o local exato onde devia ser feito o preparo do alimento e, até mesmo, quais os equipamentos a serem utilizados. Tanto o Código Sanitário quanto o de Postura procuravam, ao longo dos anos, agregar em seus textos as preocupações das autoridades médicas com uma maior definição do espaço da cozinha, que evitasse sobreposição de funções e improvisações.

O ambiente de promiscuidade (na visão das autoridades) não podia ser tolerado em um espaço tão importante, onde deveriam ser preparadas as 
refeições. $\bigcirc$ Padrão Municipal de 1920 avançava e dedicava um item inteiro à organização da cozinha na casa:

\section{COZINHAS}

Art. 138 - As cozinhas devem satisfazer as seguintes condições:

Não terem comunicação direta com compartimentos de habitação noturna e nem com latrinas; Terem área mínima de sete metros quadrados; Terem piso ladrilhado e as paredes, até um metro e cinqüenta centímetros de altura, impermeabilizados com material resistente, liso e não absorvente; Terem o teto gradeado de madeira ou tela metálica. Quando isto não seja possível pela existência de outro pavimento superior, as cozinhas terão teto de material incombustível e dispositivos especiais que garantam a ventilação permanente.

Art. 139 - As cozinhas podem ser instaladas nos embasamentos, desde que, satisfaçam as seguintes condições, além das alíneas a e c do artigo anterior:

Terem área mínima de dez metros quadrados e pé direito mínimo de dois metros e cinqüenta centímetros; Terem as paredes, acima da faixa impermeável, revestidas de pintura resistente a freqüentes lavagens; Terem o teto impermeável e de fácil limpeza;

Terem aberturas em duas faces livres e dispositivos que garantam ventilação permanente.

Art. 140 - Todas as chaminés terão altura suficiente para que a fumaça não incomode aos prédios vizinhos; pode a Diretoria de Obras, a qualquer tempo, determinar os acréscimos ou modificações que venham a tornar-se necessários.

Art. 141 - As seções de chaminé, compreendidas entre forro e telhado, e as que atravessarem paredes e tetos de estuque, tela, ou madeira, não serão construídas em material metálico ${ }^{20}$.

A legislação procurava, pois, definir minuciosamente o que deveria ser a cozinha, estabelecendo tamanho, forma de circulação e materiais utilizados, tendo a organização e limpeza como objetivo maior. Mas se essas prescrições nunca chegaram a atingir os cortiços, influenciaram outros tipos de moradia. No extremo oposto aos cortiços, estavam os palacetes. Este tipo de construção, que inicialmente se distanciou do padrão exigido pelos códigos, trouxe algumas soluções internas que, entre outras, atendiam às novas exigências sobre a cozinha e acabaram influenciando os demais tipos de habitação na cidade de São Paulo. Ao contrário dos demais tipos de casas, não havia superposição de funções, mas uma nítida divisão em três grandes zonas: estar, serviço e repouso. Espontaneamente, os palacetes introduziram o que as autoridades médicas tentavam na intervenção em cortiços e na construção de vilas operárias. Tais palacetes foram, assim, os precursores do sanitarismo, seja na organização interna com a definição clara das zonas, seja na introdução de novos equipamentos para o trabalho doméstico (HOMEM, 1993, p. 9).

Em relação ao espaço da cozinha, apesar da definição (conforme os códigos), a localização variava de acordo com as construções. Algumas vezes, ficava no porão de pé-direito alto. $\bigcirc$ Padrão Municipal de 1920 exigia, além de ventilação, a altura mínima de 2,50 m; e a ligação à sala de jantar se fazia pelo uso de uma pequena escada até a copa, que servia como ponto de 
21. Fogão americano era o nome dado aos fogões de ferro alimentados a lenha que eram importados, principalmente, dos Estados Unidos.

22. Sobre a cozinha dos palacetes, ver Maria Cecília Naclério Homem (1996, p. 29 133, 144, 201, 205, 225).

23. SÃO PAULO (Prefeitura), 1923, p. 71.

24. Segundo Maria Cecília Naclério Homem (1996, p 266), o sistema de cozinha no porão era usado em países europeus e apoiado nos equipamentos aperfeiçoados pela industrialização.

25. Há uma confusão sobre a data deste Padrão Municipal. Segundo Eudes Campos Júnior, ele foi elaborado a partir da ordem enviada pela Câmara em 11 de agosto de 1886 , posterior, portanto à reorganização das posturas municipais (6 out. 1886). Permaneceu engavetado por vários meses até ser finalmente mandado à publicação por ordem do presidente da Câmara em 17 jan. 1889. O padrão de 1889 acabou confundido com o de 1886 . Este era muito sucinto e aparecia na recodificação de 1886 , transcrito no artigo 11 . O outro tinha seis capítulos e só entrou em vigor mais de dois anos depois. Cf. Eudes Campos Júnior (1997, p. 605). Consultamos a versão do texto, de seis capítulos, que foi publicado junto com o Código de Posturas de 1886 (versão revista e ampliada do Código de 1875) na década de 40 . distribuição. Tal solução impedia o contato direto da cozinha com outras áreas da casa e impunha uma rígida separação da zona de serviço e dos empregados. O exaustor e o "fogão americano"21 resolviam o problema da fumaça, e a comida era transportada por um monta-cargas.

Na copa, antes de ser levada à sala de jantar, a comida era aquecida por um fogareiro, a princípio de querosene ${ }^{22}$. O Padrão Municipal de 1920 também legislava sobre esse novo espaço designado "copa". O artigo 142 estabelecia, para as copas e despensas (localizadas sempre próximas as cozinha), o mesmo piso ladrilhado exigido nas cozinhas ${ }^{23}$. Esta solução, de cozinha localizada no porão, era uma grande ruptura em relação aos padrões vigentes na casa paulistana, seja nos antigos sobrados urbanos, seja nas casas mais simples, onde a cozinha se localizava nos fundos, em um "puxado". Essa solução era copiada de palacetes europeus e só foi possível devido à existência de novos equipamentos domésticos ${ }^{24}$.

A solução mais comum era a localização da cozinha no térreo, no fundo da casa, ao lado da despensa e do quarto de criadas. A cozinha, neste caso, tinha ligação direta com a casa, mas localizada nos fundos, em "puxado", como era comum. Esta cozinha tinha todos os serviços urbanos, água encanada, gás, eletricidade e, em alguns casos, o fogão a gás. A região de maior concentração de palacetes em São Paulo era servida por redes de gás encanado, e vemos a presença de uma série de equipamentos domésticos elétricos - e, também, os fogões a gás - em muitos leilões publicados em jornais do período.

Caracterizando-se como um meio-termo entre os palacetes e os cortiços, está a maior quantidade de habitações em São Paulo, moradias que, nas descrições dos estudiosos, receberam diversas denominações, resumíveis em duas: "casa média" e "casa popular" (também chamada de "casa operária"). Uma das principais características nesses tipos de moradia foi a presença constante da cozinha, sempre localizada nos fundos da casa.

O Padrão Municipal publicado em $1889^{25}$ iá tinha definido para a casa popular um mínimo de três cômodos, incluindo a cozinha. Esta ficava sempre nos fundos da casa, na maioria das vezes tendo ligação direta com o corpo principal e também com o quintal. $\bigcirc$ acesso às cozinhas era direto com a sala ou com o quarto. Nas casas de três cômodos, a ligação era com a sala (que poderia muitas vezes também servir de quarto) e, nas casas de dois cômodos, a cozinha tinha acesso direto ao quarto-sala. As pequenas dimensões e suas respectivas cozinhas sugerem a superposição de funções, sem, no entanto, chegar à situação extrema dos cortiços.

Muitas dessas casas eram de imigrantes italianos (nas plantas freqüentemente estava grafada a palavra cusigna). Segundo Carlos Lemos (1989, p. 85), foram eles os responsáveis pela introdução dos pequenos fogões de ferro a carvão vegetal, os únicos que cabiam no espaço exíguo. Quando a casa possuía o tradicional fogão a lenha, ele estava encolhido dentro do cubículo denominado cozinha, localizado quase que em um puxado, uma solução ainda tradicional na casa paulista. Os novos fogões de ferro, menores e mais limpos, 
possibilitaram a atividade em uma cozinha diminuta. Esses equipamentos foram os primeiros concorrentes dos velhos fogões a lenha de alvenaria.

Devemos ressaltar que, apesar de muitas das plantas baixas de casas pequenas ou médias apresentarem o espaço da cozinha definido nos fundos dos quintais, muitas vezes essas casas eram sublocadas, provocando uma coletivização das atividades, como vemos em depoimento recolhido por Raquel Rolnik: "Eu trabalhava na Filepo, com dois teares, ganhava 200 mil réis e pagava de pensão 80 mil para o português [...] Era dois quartos e cozinha - eu vivia em um e o português e sua família vivia no outro, e a gente cozinhava tudo junto"26.

$\bigcirc$ que alguns autores costumam chamar de casa média era um tipo de habitação bastante difundida em São Paulo, principalmente nas áreas próximas ao centro (Brás, Bom Retiro, Campos Elíseos, etc..). Assim como as casas populares, este tipo de habitação também tinha o espaço da cozinha bem definido, embora reduzido. Na verdade, este tipo de moradia estava mais próximo dos palacetes, pelo menos no que diz respeito à circulação. A cozinha acabou por ser agregada ao espaço da casa, nos fundos. Mas, ao contrário da casa popular, muitas vezes estava acrescida da despensa e do quarto de empregada. A especialização da área de serviço, assim, era mais próxima do palacete. Outra diferença em relação às casas menores era o fato de as cozinha estarem ligadas diretamente à sala de jantar, e não aos quartos.

As diferenciações das cozinhas das casas descritas dificultam a definição de como tais cozinhas seriam organizadas no período. Nas moradias mais simples, o que imperava era a precariedade do espaço, exíguo, mal iluminado e mal equipado. Apenas nos palacetes eram respeitadas todas as exigências dos códigos de posturas e sanitário (superfície ladrilhada, impermeabilização das paredes etc.). Entretanto, muitas vezes o fogão a gás estava localizado na copa e servia apenas para aquecer as refeições vindas da cozinha em direção à sala de jantar (ROLNIK, 1997, p. 133).

Fogões a gás

Nesse contexto em que a cozinha passava a estar no centro das preocupações de autoridades sanitárias, o equipamento doméstico teria um papel decisivo nas transformações exigidas ${ }^{27}$. Dentre esses equipamentos, o fogão, como pudemos observar, destacava-se como centro de preparação dos alimentos na nova cozinha. $\bigcirc$ grupo Light centrou seus esforços na promoção do uso doméstico dos novos combustíveis, elegendo o fogão a gás como seu principal produto. Há, então, um considerável avanço na tecnologia doméstica (gás, eletricidade, água encanada, esgoto) colocada à disposição para o consumo (ao menos para as classes mais abastadas). A tecnologia oferecida pelas empresas estrangeiras prometia essa adequação desejada da nova cozinha à higiene e, ao mesmo tempo, procurava vencer as defasagens e os antigos hábitos coloniais considerados indesejáveis. Analisando uma propaganda de fogão a gás da
26. Entrevista realizada por Raquel Rolnik (1997, p. 80), em outubro de 1980 , com o imigrante iugoslavo Cosmo Andric Malandrin que chegou ao Brasil em 1904

27. Sobre o papel do gás, da eletricidade e dos equipamentos domésticos em São Paulo, ver João Luiz Maximo da Silva (2002). 
28. Empresa de origem belga, que se instalou no Rio de Janeiro na segunda metade do século XIX e, em 1905, teve seu controle acionário adquirido pelo grupo Light. Em 1912, a empresa lançou uma campanha publicitária para a venda de fogões em revistas como a Fon Fon.
Société Anonyme du Gaz ${ }^{28}$, Ulpiano Bezerra de Meneses (2005, p. 109) ressalta a idéia de tecnologia concebida como um valor abstrato, independente de qualquer contexto e, por isso mesmo, capaz de produzir, em qualquer circunstância, a consecução de todas as expectativas e desejos com relação ao novo equipamento - em particular na oposição ao fogão a lenha, prevendo-se que ele se tornaria totalmente obsoleto. No entanto, o confronto da imagem com o texto da publicidade deixa entrever resistências subjacentes e ônus mal encobertos, assim como uma extrema e significativa ambigüidade na identificação dos destinatários da mensagem. A tecnologia aparece, nesse caso, como uma instância abstrata e universal, impondo-se a qualquer contexto, seja nos Estados Unidos, seja no Brasil, onde há um evidente problema de descompasso.

Os fogões a gás começaram a ser fabricados nos Estados Unidos a partir de 1860, mas tornaram-se populares a partir da Exposição Universal de 1876, dominando o mercado americano nas duas primeiras décadas do século XX (BUSCH, 1983, p. 224). O gás (e posteriormente a eletricidade) tinha de ser vendido para um público desinformado e desinteressado; e, como o consumo doméstico era considerado vital para o desenvolvimento das empresas de energia, era necessário incrementar as vendas de aparelhos para uso doméstico, principalmente as dos fogões (GOLDSTEIN, 1997, p. 125).

No Brasil, o fogão (de barro ou de alvenaria) esteve ligado principalmente à lenha como combustível, e localizado no quintal, fora do corpo da casa ou em puxado. A empresa de gás aproveitou-se dessa situação e ancorou boa parte de sua propaganda nessa idéia de evolução e progresso, contrapondo lenha e gás. É difícil definir uma tipologia diacrônica dos fogões, na medida em que se sucederam, e conviveram, em séries de equipamentos com várias formas e tipos de combustíveis. Mesmo com toda essa variedade, o principal concorrente do gás era, sem dúvida, a lenha. Devido ao preço baixo e ao tipo de equipamento mais simples, era o combustível mais usado na cozinha. Os fogões de ferro (também os a lenha e os a carvão) já eram vendidos nas últimas décadas do século XIX. Existem várias referências de sua presença na cozinha de palacetes através de anúncios de jornal e catálogos de leilões. Alguns imóveis eram descritos tendo em vista as comodidades oferecidas. Além do material, a principal característica era seu tamanho e a possibilidade de uso do carvão mineral ou vegetal, muito difundido entre os imigrantes italianos, segundo Carlos Lemos (1989, p. 88). Diferenciavam-se dos anteriores porque eram compactos e feitos de ferro, comportando as mesmas características dos fogões a gás em sua morfologia geral, mas com combustível e funcionamento absolutamente distintos. Inicialmente importados dos Estados Unidos e da Inglaterra, no final do século XIX já eram fabricados em São Paulo (BANDEIRA JUNIOR, 1901, p. 13).

A produção e as vendas de fogões a gás estavam diretamente relacionadas à iniciativa da companhia, iá que esta era detentora do monopólio de produção e distribuição do combustível, por tubulações ligadas diretamente às casas. Os primeiros aparelhos foram importados diretamente pela empresa e fornecidos junto com a ligação do gás. Em suas propagandas, na tentativa de assumir o lugar ocupado pela lenha e pelo carvão, as empresas de gás 
apresentavam uma idéia de evolução cujo ápice era o gás, relegando a lenha à completa obsolescência. As propagandas, mesmo quando ressaltavam os ganhos obtidos nos novos fogões (principalmente em relação à limpeza), procuravam destacar a importância do gás.

Há poucas referências sobre a organização e a disposição dos equipamentos da cozinha. Nas propagandas, aparece claramente o domínio do fogão, como centro do espaço (claro que falamos de uma propaganda de fogão a gás, o que justifica o destaque), cercado pela pia e uma mesa de trabalho. Alguns manuais domésticos descreviam o mobiliário da cozinha:

Mobiliário na cozinha: mesa no centro para louça lavada (se a cozinha for vasta). Pias de lavagem com água quente e fria em lugar claro. Mesinha para louça a ser lavada ao lado da pia. Pano pendurado em gancho para lavar prato outro para panela. Prateleira na pia para sabão. Prateleira para utensílios longe do fogão (por causa do vapor das panelas). Mesa de cortar próxima ao fogão, depósito de lenha idem (CLESER, 1913, p. 181).

As recomendações feitas pelos especialistas apresentavam, assim, uma cozinha organizada em torno do fogão. Artigo (sem indicação de autoria) na Revista Feminina de $1918^{29}$ (Figuras 1 e 2) definia que a cozinha deveria estar aparelhada de maneira a haver eficiência e comodidade para o trabalho: "Na cozinha, que é, por certo, a parte mais importante do lar, deve-se pôr o maior cuidado, transformando-a num lugar higiênico, escrupulosamente asseado, pratico até o exagero, cômodo, muito cômodo, tanto quanto o permitam as circunstâncias" ${ }^{\prime 30}$.

Visando à limpeza e organização, a artigo define o mobiliário básico da cozinha: mesa auxiliar ao lado de dois fogões (carvão e gás) e instalação de pia com água quente e fria. Claro que, nesse caso, está se falando da cozinha ideal, organizada de forma a otimizar o trabalho doméstico, mas somente a presença de água, gás e eletricidade nas casas possibilitava tal organização. De qualquer forma, havia claramente uma preocupação inédita em relação a um espaço antes tão desprestigiado como a cozinha, que passou a mobilizar engenheiros, empresas fornecedoras de energia, educadores, autoridades públicas e, sobretudo, médicas. Esse artigo da Revista Feminina parece definir bem o papel que seria desempenhado pelo ideal da cozinha organizada. Tanto o texto quanto suas imagens definem um padrão modelar do ideal de cozinha perseguido pelas autoridades médicas com o aval público e, obviamente, das empresas de energia, que se valiam desse discurso para promover o consumo de gás e eletricidade. Na Figura 1, vemos a atividade da empregada em uma cozinha limpa e organizada. Não há o menor sinal de sujeira no momento do preparo da matéria-prima. Destaca-se, na imagem, o centro de preparação dos alimentos na cozinha: mesa e pia. Mas o texto colocado abaixo da foto ressalta os limites do modelo da cozinha higiênica e organizada, "tanto quanto permitam as circunstâncias". Claro que a realidade (seja das casas pobres, seja das casas mais ricas) impunha limites às transformações desejadas. No entanto, o texto é claro ao falar de uma situação ideal. $\bigcirc$ alvo é bem definido: "Não nos referimos
29. A Revista Feminina começou a ser publicada em São Paulo a partir de 1915 Foi uma das revistas mais im portantes do período, sendo destinada às mulheres e discutindo assuntos como identidade feminina, papel da esposa, educação. Vários artigos e propagandas estavam voltados para a organização doméstica. Cf. Heloísa Faria de Cruz (2000, p. 224).

30. Cf. Revista Feminina (n. 55, 1918). 


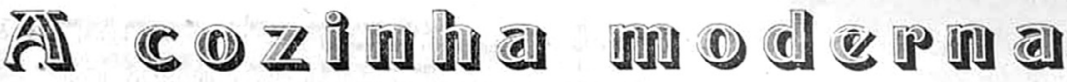

Uma cozinha deve estar apparelhada de maneira que haja o maximo de efficiencia e commodidade para 0 trabalho, que tem de ser executado nella. Não nos referimos aqui á cozinha modesta das familias que têm habitos excessivamente frugaes, mas á cozinha moderna, que tem de ser modelar.

Uma cozinha nestas condições, quer esteja appa. relhada para os grandes serviços permanentes, quer a de familia onde, por vezes, a propria cona da casa vae superintender

precisa a-

co m mo-

da r-s e a

todas a s

nece $\mathrm{s} \mathrm{s} \mathrm{i}$ -

dades, de

fórma a,

nas occa-

siōes ex-

cepcio.

naes, po-

der func-

cio $n$ a $r$

sem faltas

nem lacu-

nas de es-

pecie

$\mathrm{Na}$ co-

zinha, que

$\hat{e}$, por cer-

to, a par.

te mais

importante do lar, deve-se pôr o maior cuidado, convertendo-a num Ingar hygienico, escrupulosamente asseado, pratico até ao exaggero, commodo, muito commodo, tanto quanto o permittam as circumstancias. De. mais, uma cozinha alegre desperta alegria e inspira boa vontade para esmero do serviço, sendo limpa con vontade para our o co:tribue para crear o verdadeiro appetite, que e o de que o organismo necessita

Antes de mencionar os detalhes que são precisos para collocar uma cozinha á altura das exigencias Sos para collocar uma cozinha á altura das exigencias que lhe demos, em primeiro logar, attentar nas seguintes coisas: na preparaçăo dos alimentos antes de serem levados ao fogo ou ao forno, nos guisados em si proprios, e no moto como tem de servir cada prato. Como e de ver, tudo deve estar, com antecedencia, rigorosamente asseiado. esfregado e polido. Só assim é que se comprehende uma cozinha modelo, preparando-a para nitender a essas operaçôes tăo variadas, com a maior efficacia possivel. guardem as provisõ preparo. Muitas sucu preparo. Muitas senthoras, de indole pratica. preferem um armario, cuja parte inferior esteja provida de uma taboa postiça, que se puxa para fora, na occasiáo do serviço. fazendo-a entrar, depois do serviço executado. Na parte da taboa para cima guardam-se certas provisóes, como: arroz, assucar, pastas, conservas, e na varte de baixo, as batatas, os legumes, as verdnras frescas e .o azeite. A razăo é porque, năo só a parte inferior do armario é mais fresca por causa da visinhanca do solo, como porque a taboa movel serve para isolar as provisóes conforme a sua qualidade. A taboz, pois, substitue vantajosamente a mesa, e, o que mais é, economisa espaço e poupa passos inuteis.

Adopte-se, portanto, como elemento mais pratico, essa mesa auxiliar. O fogão deve estar ao lado. Essa mesa precisa ser recoberta de zinco ou de oleado branco, com bordos mais elevados, em feitio de taboleiro.
Serve isso para evitar que corram para o chão as gorduras e as aguas. Sobre essa mesa é que se executam todos os preparos que vão ser empregados na comida. Um detalhe que merece attenção é o assento. Uma cadeira commum nảo serve, por causa do espaldar. O melhor é uma banqueta alta, que permitta á cozinheira estar sentada emquanto prepara as salsas ou descasea as batatas, servindo the tambem para approximal-a do fogão de gaz, segundo os casos. Advirta-se atambem pque muihoras em que a cozinheira tem de estar de pe e ess es sã $0-1$ h he

De resto, a te $\mathrm{m}$ do fogão com m um ou econom i co, é requisito indispenha ja outro, electrico ou

de gaz, e, entre um e outro, um deposito de agua quente, guardada no deposito, é providencia da cozinheira, que, sem ella, se vê forçada a malbaratar o seu tempo, a aquecer agua, toda vez que precisa.

Nas casas modernas esse mesmo deposito serve para abastecer de agua quente o compartimento de ba-

A installação da pia ou lavadouro é uma das coisas mais importantes da cozinha. A pia deve ser bastante ampla e de ferro esmaltado, servida por duas (

O rebordo plano que circumda a pia, onde seempilham os pratos e talheres para lavar, precisa ser le. vemente inclinado para dentro, para que as aguas entornadas não escorram para fóra. O lavadouro terá a altura conveniente, porque, muito alto, fatiga terrivelmente os braços de quem trabalha sobre elle, e, muito baixo, obriga a pessoa a estar curvada, o que, como se sabe, comprommette os rins.

Outro pormenor que não é para desprezar é o sitio onde se haja de collocar o lavadouro. E' preferivel deante de uma janella, para que recolha maior quantidade de luz afim de ser bem verificada a limpeza dos apparelhos, sem receio ás lacunas de asseio. Mas não é só pela luz mas porque, como o trabalho da limpeza e esfrega é summamente desagradavel para quem quer que se dedique a eile, o ar sempre renovado se faz necessario ao olfato de quem trabalha entre os diversos cheiros que erram no ambiente. Quanto mais perto estiver a pia do armario de pratos ou da prateleira onde se empilham as cassarolas e outros utensilios, me. thor. e serão mais poupados os passos inuteis, considerando ainda que esteja na visinhança da despensa. Os utensilios de outra especie, como escovas, esfregöes, esponjas, sabões, tijolos de arear, frascos de desinfectantes, pannos, etc., requerem tambem um logar apropriado e que esteja ao abrigo do pó. Inutll é accrescentar que a illuminação ha de ser perfeita. Além
da lampada electrica no centro, para distribuição geral

Figura 1 - "A Cozinha Moderna". Revista Feminina, n. 55, dezembro 1918, s.n.p. Acervo do Arquivo do Estado de São Paulo, São Paulo. 


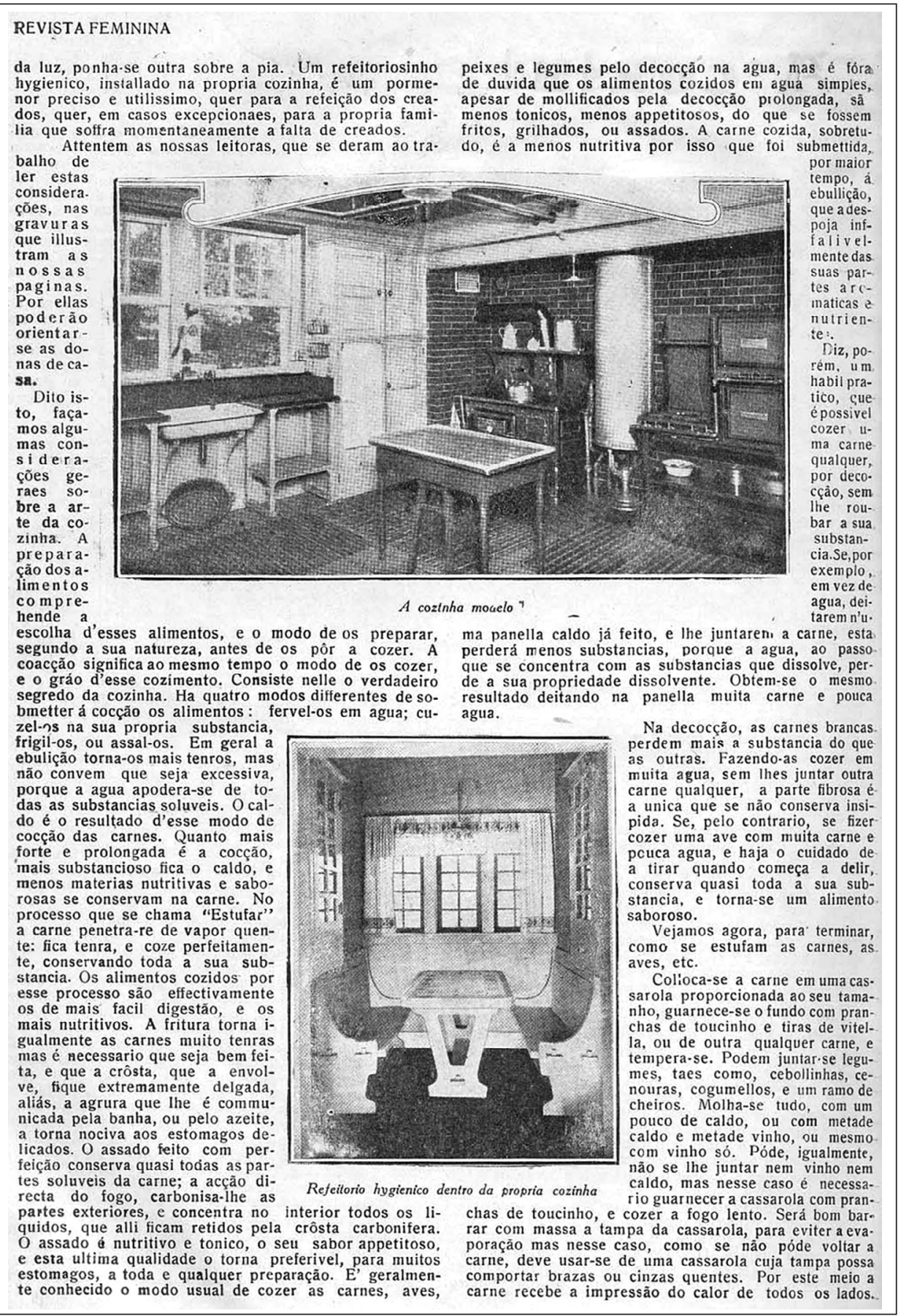

Figura 2 - "A Cozinha Moderna". Revista Feminina, n. 55, dezembro 1918, s.n.p. Acervo do Arquivo do Estado de São Paulo, São Paulo. 
31. Ibidem.

32. Um dos principais veículos das propagandas de equipamentos domésticos foi a revista Fon Fon , que circulou no Rio de Janeiro de 1907 a 1956 e foi uma das revistas ilustradas mais importantes do período (chegando a circular em São Paulo). Seu caráter de "mundanismo" a colocava em oposição às grandes revistas literárias, já que se dedicava também à política, mesclando humor, comentários sociais e notícias do cotidiano, além de uma grande quantidade de propagandas. Não existem informações sobre sua tiragem, mas tratava-se de uma revista de grande importância, na qual surgiram vários desenhistas e escritores representativos, tendo uma grande penetração nas camadas médias da população urbana. Cf. Brito Broca (1975, p. 43). aqui á cozinha modesta das famílias que têm hábitos excessivamente frugais, mas á cozinha moderna, que tem de ser 'modelar'"31.

A expressão "famílias com hábitos excessivamente frugais" é um elegante eufemismo para pobreza. Claro que o artigo está diretamente relacionado à possibilidade de aparelhamento da cozinha pelas classes mais abastadas. Mas devemos novamente ressaltar que a cozinha mostrada é um modelo, não existindo como tal, mas representando um ideal.

Na Figura 2, temos a cozinha com seus principais elementos e mobiliário, que caracterizariam o ideal da cozinha moderna: pia, mesa de trabalho e fogões (carvão e gás) perfeitamente alinhados e ordenados em um espaço limpo e organizado. A legenda "cozinha modelo" estabelece esse padrão, expresso visualmente como o modelo da cozinha desejada.

Ainda no mesmo artigo da Revista Feminina, vemos a exploração das possibilidades do uso dos novos equipamentos para variar e enriquecer o cardápio, não apenas na forma de novos pratos, mas também nas renovadas formas de preparo propiciadas pela cozinha moderna. Em perfeita sintonia com a transformação exigida da cozinha, o artigo procura definir objetivamente práticas identificadas com novos padrões de limpeza e controle, no qual o fogão a gás teria um papel de destaque.

No caso brasileiro, podemos dizer que tais questões foram utilizadas pela medicina higienista, que pregava a limpeza e organização da casa. Devemos reiterar que a entrada de empresas de gás e eletricidade no Brasil teve uma grande influência nesse processo. Com a venda de aparelhos mecanizados para a cozinha, tais empresas se utilizaram tanto do discurso higienista quanto dos estudos de organização e padronização da cozinha, muitas vezes explorando os mesmos princípios de educação doméstica.

Higiene, moral e negócio

Nesse contexto, a atuação das empresas de energia, reunidas em torno do grupo Light, foi decisiva nas transformações que se operavam no espaço doméstico. A mediação da empresa (concessionária do poder público) ligava definitivamente o espaço doméstico ao espaço urbano, por intermédio das redes de abastecimento, com todas implicações daí decorrentes. $\bigcirc$ discurso da higiene, presente no discurso médico e no do poder público, foi utilizado pelas empresas de energia na promoção, principalmente, do gás para fins domésticos.

Nas propagandas, são freqüentes as referências à importância do fogão a gás na higiene da cozinha ${ }^{32}$. Estavam presentes dois pontos principais: a limpeza da casa e a alimentação sadia. Esses temas eram direcionados não apenas à mulher, mas também ao homem. Em propaganda, de 1913, da Société Anonyme du Gaz, sob o título "um laboratório importante", o texto dirige-se ao homem perguntando: "Em qual das divisões da sua casa é o Snr. mais exigente?". A resposta, obviamente, é a cozinha e a justificativa completava: "O laboratório 
importante onde se fabricará diariamente a boa saúde de sua esposa e seus filhos, se para preparo da comida se utilizar o aparelho mais sanitário e higiênico que a civilização do nosso século criou: $\bigcirc$ fogão a gás"33.

$\bigcirc$ texto se dirige diretamente àquele que seria o responsável pela compra do aparelho e do combustível, apelando para argumentos racionais e técnicos. Nas propagandas da Société Anonyme du Gaz em que aparece a imagem do fogão a gás, o processo tecnológico está presente apenas naquilo que é mais evidente: os controles da chama. As eventuais dificuldades de manuseio e entendimento - e, mais ainda, seu funcionamento - continuavam misteriosos. Nas imagens, não aparece a conexão do fogão com a rede, mas podemos inferir, pela leitura do texto, a dependência à empresa, seja na manutenção, seja na presença de medidores e tubulações. Poucas propagandas mostram o fogão em funcionamento, e, quando o fazem, o trabalho aparece como uma atividade fácil e prazerosa. Nas poucas imagens em que aparece a mulher usando o fogão, ela sempre está posicionada lateralmente, para permitir uma melhor visualização do equipamento. Mas sua postura é elegante, sugerindo pouca mobilização e sempre com o trabalho em andamento, sem mexer nos controles. Sua única preocupação parece ser a de supervisionar o andamento do trabalho. A idealização da cozinha centralizada no fogão aparece de forma exemplar em uma propaganda da Société Anonyme du Gaz ${ }^{34}$ que associa o fogão à moda, com uma dona de casa usando um vestido social (jupe-cullote ${ }^{35}$ ) para cozinhar. No caso deste anúncio, a figura da empregada está ausente, em uma imagem idealizada do trabalho doméstico em torno da figura da dona de casa associada à moda (Figura 3).

Também o discurso médico, adotado inclusive por engenheiros, arquitetos e autoridades públicas, aparece no discurso publicitário, associando o fogão a gás com a higiene. Ao homem, como destinatário dessa propaganda na qualidade de comprador, era enfatizada a necessidade da alimentação sadia. Além de propiciar higiene e asseio, o fogão teria a capacidade de transmitir essas qualidades à comida nele preparada. E, para isso, o papel da cozinheira - e mais ainda o da dona de casa - seria decisivo, no uso adequado do fogão e na escolha do cardápio. $\bigcirc$ papel do homem estaria esgotado na aquisição do fogão a gás e do pagamento mensal do fornecimento do gás, dados que, nessa propaganda, não são apresentados especificamente.

Os eventuais ganhos obscureciam a crescente dependência a que estaria submetida a casa. Devemos lembrar que o fornecimento de gás funcionava através de redes de tubulação de gás, com implicações referentes a abastecimento, manutenção, preço etc. A relação com o fornecedor de serviços entrava em uma nova esfera. A mediação tornava-se indiferenciada e profissional. A companhia era a única mediação possível, sem as antigas relações pessoais de proximidade com eventuais fornecedores que atendiam de porta em porta. As antigas sociabilidades eram substituídas por relações empresariais e capitalistas, reguladas por contratos, com direitos e deveres estabelecidos e (nem sempre) protegidos. espécie de saia-calça, de origem francesa, que teria sido introduzida no país na década de 1910 . 


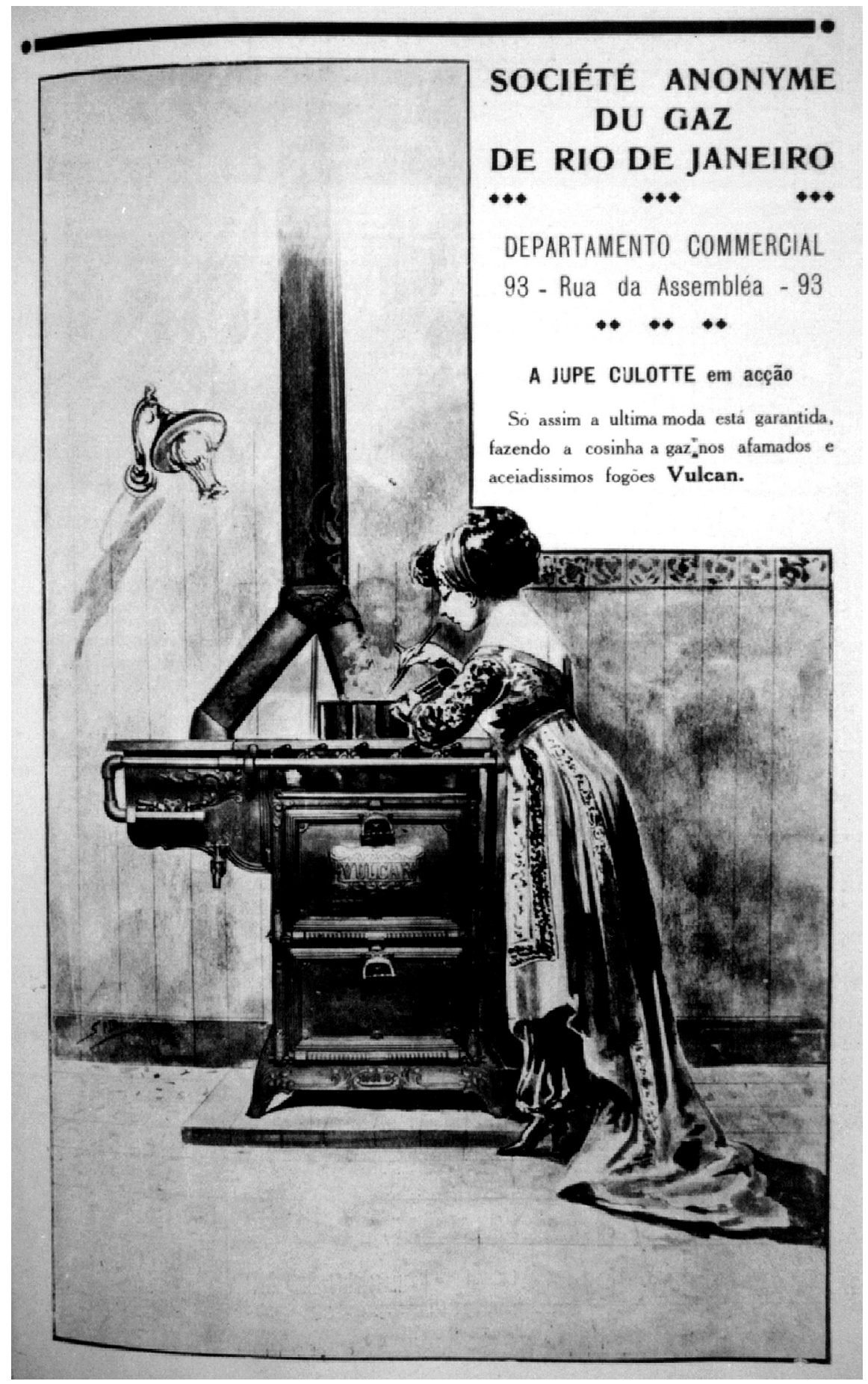

Figura 3 - Propaganda da Société Anonyme du Gaz. Revista Fon Fon, n. 16, abril 1911 , s.n.p. Acervo da biblioteca central da Pontifícia Universidade Católica, São Paulo. 
Em suas propagandas, a companhia de gás não explicitava, em nenhum momento, a dependência a que a casa passaria a estar submetida, mas oferecia "gratuitamente" vários serviços que comprovavam esta dependência. Na maioria das propagandas das empresas de gás, o fogão sempre aparece como fonte direta de ganhos, seja em economia de tempo ou dinheiro, seja no sentido de evitar aborrecimentos ou sujeira na cozinha. Mas sua evidente ligação com a empresa (e com toda uma rede de infra-estrutura) estava encoberta pelo discurso. Nas propagandas, podemos inferir o grau dessa dependência nos serviços oferecidos: "A Companhia gratuitamente fará a ligação do fogão, e ainda o inspecionará, limpará e conservará durante dois anos. Se a sua casa não tem medidor, o acréscimo de despesa será então o pagamento de um pequeno depósito, além da compra do fogão"36.

Este complexo de relações se traduziu em reconfigurações do espaço da moradia, ligada aos interesses privados capitalistas e regulados pelo poder público. Mas, como em todo sistema, um dos principais fatores estava associado à adaptabilidade. A entrada da energia elétrica e do gás, tendo na ponta os aparelhos domésticos, trouxe modificações e resistências, mas também adaptações. As noções de progresso, exploradas pelas empresas de energia e endossadas pelas elites, inseriam-se com dificuldade na ordem social brasileira. As propagandas de fogões são, ao mesmo tempo, evidências desse descompasso e uma tentativa de escamoteá-lo.

Em tal quadro, essas empresas tiveram um papel de destaque, utilizando-se do discurso higiênico e dos anseios de ordenação do espaço doméstico; e, ao mesmo tempo, participando ativamente desse processo, não como subproduto, mas como parte integrante. Mas essas transformações não ocorreram naturalmente, como simples substituição de uma forma obsoleta de cozinhar por outra mais moderna, como queriam fazer crer as propagandas. Dois fatores são importantes na análise desse percurso: as dificuldades de adaptação corporal às novas práticas em novos equipamentos e as novas noções de tempo aplicadas à vida e ao trabalho doméstico. As novas mediações da tecnologia doméstica e sua gestão de forma privada, provocaram mudanças e dificuldades, enfrentadas pelas empregadas e suas patroas.

Era na cozinha - e por intermédio dos equipamentos domésticos que uma nova relação entre espaço urbano e espaço doméstico estava em desenvolvimento na cidade de São Paulo. A viabilização e comercialização de uma nova tecnologia, aplicada ao trabalho doméstico e distribuída através de redes, trouxe um grau de dependência da casa às novas relações, que extrapolaram os antigos limites do espaço doméstico. Esse processo submeteu a casa e a rua às relações técnicas e econômicas mediadas por novos agentes e novas formas de abastecimento e prestação de serviços. As propagandas e outras formas de divulgação foram usadas para diminuir a estranheza em relação à nova tecnologia e, ao mesmo tempo, escamotear custos, apresentando o produto como sendo completamente autônomo em relação ao sistema. Em compensação, vemos uma articulação (de amplas conseqüências) entre poder público, capital (capital estrangeiro e seus interesses) e infra-estrutura, redefinindo um novo espaço urbano e doméstico. 


\section{REFERÊNCIAS}

ALMEIDA, Guilherme. A casa. Revista do Arquivo Municipal, São Paulo, n. 82, p. 177-184, mar.abr. 1942.

BANDEIRA JUNIOR,A F. A indústria no estado de São Paulo em 1901. São Paulo:Typographia do Diário Oficial, 1901.

BRITO, Mônica Silveira. A participação da iniciativa privada na produção do espaço urbano: São Paulo 1890-1911.2000. Dissertação (Mestrado em Geografia Humana) - Faculdade de Filosofia, Letras e Ciências Humanas, Universidade de São Paulo, São Paulo, 2000.

BROCA, Brito. A vida literária no Brasil: 1900. Rio de Janeiro: José Olympio, 1975.

BRUNA, Paulo. Os primeiros arquitetos modernos: habitação social no Brasil 1930-1950. 1998. Tese (Livre Docência em Projeto Arquitetônico) - Faculdade de Arquitetura e Urbanismo, Universidade de São Paulo, São Paulo,1998.

BUSCH, Jane. Cooking competition: technology on the domestic market in the 1930's. Technology and Culture, Chicago, v. 24, n. 2, p. 222-245,Apr. 1983.

CAMPOS JÚNIOR, Eudes. Arquitetura paulistana sob o império: aspectos da formação da cultura burguesa em São Paulo [1997] Tese (Doutorado em Arquitetura) - Faculdade de Arquitetura e Urbanismo, Universidade de São Paulo, São Paulo, 1997.

CLESER,VeraA. O lar doméstico: conselhos para uma boa direcção da casa. Rio de Janeiro: Francisco Alves, 1913.

COMGÁS. Antecedentes históricos: início da iluminação pública em São Paulo. São Paulo: Companhia de Gás de São Paulo, 1987.

COSTA, Jurandir Freire. Ordem médica e norma familiar. Rio de Janeiro: Graal, 1999 (Biblioteca de filosofia e história das ciências, 5).

COWAN, Ruth Schwartz. More work for mother. The ironies of household technology from the open hearth to the microwave. New York: Basic Books, 1983.

CRUZ, Heloísa de Faria. São Paulo em papel e tinta: periodismo e vida urbana, 1890-1915. São Paulo: Imprensa Oficial, 2000.

DECCA, Maria A. Guzzo. No interior da morada operária. São Paulo - 1890/1940. Anais do Museu Paulista, São Paulo, n. 23, p. 97-109, 1984.

DIAS, Maria Pinho. Desenvolvimento urbano e habitação popular em São Paulo 1870-1914. Monografia (Trabalho de Graduação Interdisciplinar em Arquitetura) - Faculdade de Arquitetura e Urbanismo, Universidade de São Paulo, São Paulo , 1974. 
DIAS, Renato Feliciano (Coord.). Panorama do setor de energia elétrica no Brasil. Rio de Janeiro: Centro de Memória da Eletricidade no Brasil, 1988.

FREIRE,Victor Silva. Códigos sanitários e posturas municipais sobre habitação. Boletim do Instituto de Engenharia. São Paulo, v. 1, n. 3, p.229-427, 1918.

GIEDION, Siegfried. Mechanization takes command: a contribution to anonymous history. New York:W.W. Norton, 1948.

GOLDSTEIN, Carolyn M. From service to sales: Home economics in Light and Power, 1920-1940. Technology and Culture, v. 38, n. 1, p. 121-152, Jan. 1997.

HAYDEN, Dolores. The grand domestic revolution. Cambridge, MA: MIT Press, 1981.

HOMEM, Maria Cecília Naclério. Mudanças espaciais na casa republicana.A higiene pública e outras novidades. Pós: revista do programa de pós-graduação em Arquitetura e Urbanismo da Fauusp, São Paulo, USP, FAU, v. 3, p. 5-18, jun. 1993. O palacete paulistano e outras formas de morar da elite cafeeira (1867-1918). São Paulo: Martins Fontes, 1996.

O princípio da racionalidade e a gênese da cozinha moderna. Pós: revista do programa de pós-graduação em Arquitetura e Urbanismo da Fauusp , São Paulo, USP, FAU, v. 13, p. 124-153, 2003.

Os primeiros cortiços paulistanos. In: SAMPAIO, Maria Ruth Amaral de (Coord.). Habitação e cidade. São Paulo: FAU-USP; Fapesp, 1998. p. 9-38.

LEMOS, Carlos A. C. Cozinhas, etc.: um estudo sobre as zonas de serviço da casa paulista. São Paulo: Perspectiva, 1978 (Debates, 94).

A República ensina a morar (melbor). São Paulo: Hucitec, 1999.

Alvenaria Burguesa: breve história da arquitetura residencial de tijolos em São Paulo a partir do ciclo econômico liderado pelo café. São Paulo: Nobel, 1989.

LIMA, Sandra Lúcia Lopes. Espelbo da mulber: Revista Feminina (1916-1925). 1991. Tese (Doutorado em História Social) - Faculdade de Filosofia, Letras e Ciências Humanas, Universidade de São Paulo, São Paulo, 1991.

MARTINS,Ana Luiza. Revistas em revista: imprensa e práticas culturais em tempos de República. São Paulo (1890-1922). São Paulo: Edusp; Imesp, 2002.

MASCARO, Sonia de Amorim. A Revista Feminina: imagens de mulher (1914-1930). 1982. Dissertação (Mestrado em História Social) - Faculdade de Filosofia, Letras e Ciências Humanas, Universidade de São Paulo, São Paulo, 1982.

MATOS, Maria Izilda Santos de. Porta a dentro: criados de servir em São Paulo, 1890-1930. In: BRUSCHINI, M.; SORJ, B. (Coord.). Novos olhares: mulheres e relações de gênero no Brasil. São Paulo: Marco Zero, 1994. p. 193-203.

MAWE, John. Viagens ao interior do Brasil. Rio de Janeiro: Zélio Valverde, 1944 [1812].

Annals of Museu Paulista.v. 15.n.2. July-Dez. 2007. 
MELLO, Francisco Figueira de. Habitações collectivas em S. Paulo. Boletim da Sociedade de Medicina e Cirurgia de São Paulo, São Paulo, v. 9, n. 4, p. 291-295, jun. 1926.

MENESES, Ulpiano T. Bezerra de. O fogão da Société Anonyme du Gaz. Sugestões para uma leitura histórica de imagem publicitária. Projeto História, São Paulo, n. 21, p. 105-119, nov. 2000.

RAGO, Margareth. Do cabaré ao lar: a utopia da cidade disciplinar - Brasil 1890-1930. Rio de Janeiro: Paz e Terra, 1987.

REVISTA Feminina, 1915-1926.

REVISTA Fon Fon, 1907-1930.

ROLNIK, Raquel. A cidade e a lei: legislação, política urbana e territórios na cidade de São Paulo, São Paulo: Fapesp; Studio Nobel, 1997.

SÃO PAULO (Estado). Repertório de legislação sobre o serviço sanitário do Estado de São Paulo, Typographia do Diário Oficial, 1907.

. Departamento Estadual do Trabalho. Boletim do Departamento Estadual do Trabalbo, 1911-1927. Biblioteca da Faculdade de Saúde Pública-USP.

SÃO PAUlO (Prefeitura). Código de Posturas do Município de São Paulo, 6 out. 1886. Biblioteca da FAU-USP.

. Relatório da Comissão de Inspeção de Residências e Cortiços dos Trabalhadores no Distrito de Santa Efigênia para a Câmara Municipal de São Paulo, 1893.Arquivo do Estado de São Paulo.

Lei municipal n. 2232, de 9/11/1920. Estabelece o "Padrão Municipal" para construções particulares no município. Boletim do Instituto de Engenharia, São Paulo, v. 5, n. 21, p. 69-87, 1923.

SILVA, João Luiz Maximo da. O impacto do gás e da eletricidade na casa paulistana 1870-1930: estudos de cultura material no espaço doméstico [2002]. Dissertação (Mestrado em História Social) - Faculdade de Filosofia, Letras e Ciências Humanas, Universidade de São Paulo, São Paulo, 2002.

SZMRECSÁNYI,T.; SAES, Flávio. Energia elétrica e capital estrangeiro: o caso da São Paulo Light. 1899-1904. Resgate: revista de cultura, Campinas, n. 4, p. 9-17, 1992.

SOUZA, Edgard de. História da Light: primeiros 50 anos. São Paulo: Eletropaulo, 1989.

Artigo apresentado em 8/2007. Aprovado em 9/2007. 